\title{
ALTER EGO ONLY FOUR TIMES? THE CASE STUDY OF BUSINESS PROFITS IN THE VISEGRAD GROUP
}

\author{
Katarína Valášková1, Beáta Gavurová2, Pavol Duurana², \\ Mária Kováčová4
}

\footnotetext{
1 University of Žilina, Faculty of Operation and Economics of Transport and Communications, Department of Economics, Slovakia, ORCID: 0000-0003-4223-7519, katarina.valaskova@fpedas.uniza.sk;

2 Tomas Bata University in Zlín, Faculty of Management and Economics, Center for Applied Economic Research, Czech Republic, ORCID: 0000-0002-0606-879X, gavurova@utb.cz;

3 University of Žilina, Faculty of Operation and Economics of Transport and Communications, Department of Economics, Slovakia, ORCID: 0000-0001-5975-1958, pavol.durana@fpedas.uniza.sk;

4 University of Žilina, Faculty of Operation and Economics of Transport and Communications, Department of Economics, Slovakia, ORCID: 0000-0003-2081-6835, maria.kovacova@fpedas.uniza.sk.
}

\begin{abstract}
The paper studies a new point of view and the approach to profit as an inherent part of business finance as well as a symbol of every healthy economy. The fundamental function of the profit is a stimulus; it means initial motivator of the business activity. The profit provides core resources for survival at the business start and after the stabilization, it is the synonym for progress. The aim of this paper is to detect significant change-points in times series of EBITDA during the analysed period in every country of the Visegrad Group to recognize the progress years in the monotonic development. We use a method of homogeneity test of time series that delivers significant robust results. We observe the variable EBITDA to eliminate different tax, interest and depreciation policies of these emerging countries. The original research of this article is based on empirical results of business profits of the sample of 3,853 enterprises covered by the broad theoretical review. Firstly, we identify missing values; and detect the outliers by Z-score and Grubbs test. EBITDA of 1,058 Slovak enterprises, 688 Czech enterprises, 1,376 Polish enterprises and 731 Hungarian enterprises is analysed during the period from 2010 to 2018. We eliminate the inconsistent observations and construct average values of EBITDA. Secondly, we prove normality by Jarque-Bera test, and support it by Shapiro-Wilk test, Anderson-Darling test, Lilliefors test to deliver reliable results. Thirdly, we find an independency of distribution that confirm randomness by the Box-Pierce test. And finally, we identify the years that affect heterogeneity of EBITDA in the countries of the Visegrad Four. We uncover some really surprising results. For all countries in the Visegrad Four, the year 2013 is detected as a change-point at a significance level of 0.05 . This significant year shifts EBITDA between two homogeneous series with corresponding central lines and recognizes the similar annual development within the groups. In addition, we discuss the results to the areas and factors affecting the business risk. The adjustable area represented by the business dynamism has no significant impact on the development of EBITDA. The uncontrollable macroeconomic factors such as a GDP, unemployment rate, inflation rate, average monthly gross wage, and Ease of doing business index demonstrate the same development of Slovak, Czech, Polish and Hungarian enterprises. We connect our gained results to the undisputed influence of these factors and its derived components on monotonic development of EBITDA. Despite the fact, that the countries are not economically interconnected as they used to be in the past, in has to be underlined that their mutual relations are still very narrow and close and that might be the reason, why identical results are achieved in the countries with divergent development.
\end{abstract}

Keywords: Business finance, change-point, profit, uniformity, Visegrad Four.

JEL Classification: G30, G32. 
APA Style Citation: Valášková, K., Gavurová, B., Ďurana, P., \& Kováčová, M. (2020). Alter Ego Only Four Times? The Case Study of Business Profits in the Visegrad Group. E\&M Economics and Management, 23(3), 101-119. https://doi.org/10.15240/tul/001/2020-3-007

\section{Introduction}

Globalization is the process of international integration arising from the interchange of world views, products, ideas and other aspects of the culture. Globalization brings together new opportunities also new threads (Vagner, 2016). Many studies have been published that assess business environment quality, risk, determinants, and influencing factors (Rowland, 2019). The enterprises must define the nature of the profit, the conditions of its creation, their importance for society, the legislative framework, the particular aim and also the financing conditions in the country (Vagner \& Zadnanova, 2019) to be on the side of winners in the global market. The aim of this paper is to detect significant change-points in times series of EBITDA during the analysed period in every country of the Visegrad Group to recognize the progress years in the monotonic development. We identify the research gap in this issue because no studies focus on homogeneity of time series of business profit both in the area of Visegrad group and in the European Union. Detection of the change-points (break years within the development) in time series of profits in Visegrad Four has not been realized and the results of the analysis should be highlighted not only for the theoretical importance but also for the importance for business practice. To show the break point, when the changes in the profit development occurred - dividing the development into two homogenous series - and gain the causes of their existence could mean the starting point to understand them, used them and finally, even to force them to more change-points with positive consequences.

The results of the analysis play an important role in the research on the earnings management phenomenon in the selected European countries, where the incentive is to reveal the existence of earnings management by time series analysis. The investigation of the presence of manipulation with earnings in these countries may contribute to the justification of earnings management occurrence. As the issue of the manipulation with earnings in these countries is discussed by researchers and academicians only in Poland, and the level of knowledge in other three countries remains unexplored, the significance of the analysis of unique country samples has to be underlined. Determination of earnings management practices has to be depicted as it is a significant factor of business partners' protection against risks which can appear if distorted and incomplete information is presented by the enterprises in their financial reports.

Our paper is structured as follows. Firstly, the theoretical background is presented, concentrating on the analyses of different aspects associated with the issue of business profits. Secondly, the materials used and methods applied in this research are portrayed. The next part of the paper presents the research results and analyses the results in detail. Finally, the limitations of the study, potential areas of further research as well as the conclusions are discussed.

\section{Theoretical Background}

The theoretical background of the paper focuses on four main domains which have significant effect on the success of the corporate transformation process. They reflect the basic functions of corporate earnings; to be able to make decisions about the crucial economic issues of an enterprise, to ensure key sources needed for the sustainable development of a company and its innovation policy and to redistribute the earnings achieved (e.g. corporate citizenship) in order to boost the performance of enterprises.

\subsection{Maximization versus Ethics}

Entrepreneurship is a process that recognizes opportunities in the environment or society which involves mobilizing resources in providing improved goods and services with the aim of profit maximization as a reward of risk-taking (Kowo et al., 2019; Belás \& Sopková, 2016). Risk management represents a significant contribution to the increasing competitiveness of enterprises and their profits in changes of the business environment (Hudakova et al., 2018). Anand et al. (2019) solve the profit maximization problem by optimization of the 
overall advertising duration and advertising take-off point. An algorithm to solve the optimal solution is also provided by Chuang and Wu (2019). They maximize the profit by determining the supplier's optimal process mean and investment amount, the retailer's optimal number of shipments, order and maximal backorder quantities. Shahriar et al. (2016) examine whether the profit orientation affects its decision to extend loans. According Rahman et al. (2017) risky borrowers need to pledge collateral and the reduction of asymmetric information can lower the incidence of collateral for firms. Rahman et al. (2018) show that service-oriented firms use less trade credit than manufacturing firms. Primeaux and Stieber (1994) and Primeaux (1997) propose a model for business ethics which arises directly from business practice. This model is based on a behavioural definition of the economic theory of profit maximization and situates business ethics within opportunity costs. Within that context, they argue that good business and good ethics are synonymous, that ethics is at the heart and centre of business, that profits and ethics are intrinsically related. The most successful enterprises are those which have realized that their greatest assets are their employees and therefore take special care of them (Angelova et al., 2017). Manish and Sutter (2016) oppose that entrepreneurs are motivated not only by the desire to maximize profits but also by the desire for mastery. The economy and the digital age have changed the nature of work and management. More people than ever before need to master ethical thinking skills (Friedman et al., 2019). The efficiency argument for the for-profit maximization says that corporations and their managers should maximize profits because this is the course of action that will lead to an 'economically efficient' or 'welfare maximizing' outcome (Jensen, 2001, 2002). Hussain (2012) criticizes these studies and argue that the fundamental problem with this argument is not that markets in the real world are less than perfect, but rather that the argument does not properly acknowledge the personal sphere. Morality allows each of us a sphere in which we are free to pursue our personal interests, even if these are not optimal from the social point of view. But the efficiency argument does not come to terms with this feature of social life. Singer (2013) argues that Hussain's strategy of seeing the corporation as an extension of the private sphere is not a very effective way of challenging the profitmaximization norm, but Kristofik et al. (2019) and Robson (2019) reply Hussain (2012) and argue that even if firms are required to maximize their social welfare contributions, they are not necessarily required to maximize their profits. Anderson et al. (2018) examine the possible pathways to the profit; the impact of improvements in marketing skills relative to finance skills. These gains differ substantially between the two groups. The marketing group achieves greater profits by adopting a growth focus on higher sales, greater investments in stock and materials, and hiring more employees. The finance group achieves similar profit gains but through an efficiency focus on lower costs. Podhorska et al. (2019) connect these two groups. They investigate the correlation between profitability included in the category of financial-economic analysis and goodwill of enterprises represented by residual incomes. Significant dependence between these variables is detected. Managers are often caught between the expectations of ethical consumers and the profit-maximizing expectations of the investors (Kotek et al., 2018). It has been the traditional belief that profits and ethics are at odds with each other in the world of business. Corporate governance appears to be a hindrance or a drag on profit maximization (Ghosh et al., 2011). Ghosh et al. (2011) show that moral codes, public interest and social values pose no threat to profit maximization of any firm. Gazzola et al. (2019) explore various motivations and take into consideration both extrinsic and intrinsic drivers also monetary and nonmonetary benefits. The conceptual and structural model mainstreams a motivational continuum starting from profit maximization to development.

\subsection{Sustainable Development to Industry 4.0}

It was only in the 20th century, with the unification of large-scale industry and finance capital that the modern notion of profitability as return on capital employed finally developed (Toms, 2010). Aram and Cowen (1990) highlight the need of the development of effective management teamwork out of a planning process for increased profit and details the investment required in strategic process development which would guarantee 
the critical five per cent difference to ensure the successful growth and adaptability of the company. The proposal of Altman and Dillon (2005) can be conceptualized as a profitrelated loan scheme or as a form of capped public investment. It seeks to address key elements of the market failure that exist in relation to financing development. George and Kabir (2008) examine the phenomenon of profit redistribution in business groups and relate redistribution with the underperformance of group-affiliated firms relative to unaffiliated firms. The study also documents that profit redistribution is more pronounced in groups of large sizes and high levels of corporate control. The study of Leite et al. (2013) aimed to analyse and test the development of an alternative business performance metric: profit per employee (PE). An empirical study showed that the correlation between PE and share prices was higher and more significant than the correlation with traditional metrics for the firm most intensive in intellectual capital. For the other firms, traditional metrics presented higher correlation. The concept of Industry 4.0 marks a new phenomenon of modern business. Industry 4.0 and its other synonyms such as Smart Manufacturing, Smart Production or the Internet of Things have been identified as major contributors in the context of the digital and automated manufacturing environment. The term Industry 4.0 comprises a variety of technologies to enable the development of the value chain resulting in reduced manufacturing lead times, as well as improved product quality and organizational performance (Kamble et al., 2018). Felstead (2019) develops a conceptual framework based on a systematic and comprehensive literature review on systems in Industry 4.0 to keep the business profitable. Furnham (2019) performs reviews and advances existing literature concerning big data-driven algorithmic decision-making to estimate profits. Trigos and López (2019) add to these systems by design, capacity, maintenance and salvage value. Hayhoe et al. (2019) inspect the relevant literature on sustainable manufacturing in Industry 4.0 , providing both quantitative evidence on trends and numerous in-depth empirical examples to being profitable in the context of Industry 4.0. Stanovcic et al. (2016) find that firms in which top management supports the development of employees' idea and have regular employees' meetings related to innovative activities are likely to report higher profit generated by innovations. Authors' results underline the crucial role of human resource practices in the process of innovations that generates profitability for firms.

\subsection{Innovations as a Driver}

Modern economy is permanently evolving and becoming more interdependent, especially in the age of globalization (Krastev et al., 2020). The rapid reshaping of the global economic order requires fundamental shifts in international business scholarship and management practice (Petricevic \& Teece, 2019). The response to these global phenomena may be the ability to understand and implement business innovations and profit from them. The final, third development stage of each country is also named Innovation-driven stage. Hallberg and Brattström (2019) show that knowledge revealing may have a positive effect on profits when there are strong indirect network effects; when firms are protected from imitation by causal ambiguity, complementary assets, and intellectual property; and when the innovating firm faces high technological uncertainty. Tuyls and Pera (2019) provide theoretical and empirical research on innovative data-driven systems. Capponi et al. (2019) investigate the use and perceived effectiveness of different appropriate strategies in the context of break through innovations. They find that firms consistently combine formal and informal intellectual property to prevent imitation and that their strategies can vary over time according to the phase of development of the innovation and lead to increasing business profit. Desyllas and Sako (2013) explicate the complex mechanism and dynamic capability for business profit from business model innovation. Their paper examines how an incumbent firm could increase profit from the approach of business model innovation and how long-term competitiveness depends on the specialized complementary asset. The study of Su et al. (2013a) examines the moderating effects of legal, marketing, and technological capabilities on the relationship between product innovation and firm performance in different environmental conditions in order to identify how a firm can leverage these capabilities to profit from product innovation. It is an addition of the previous study of Su et al. (2013b) in which they point out that R\&D capability 
and marketing capability are two important generators of business profit. Pinxterhuis et al. (2019) suggest that the key principles, enablers and barriers, sourced from literature, provide a framework for regular reflection that will help to maintain a co-innovation approach and to define interventions or adjustments of project activities to improve the profit. Lazonick et al. (2013) discuss that Apple is changing business model of large firms. By employing the theory of innovative enterprise to analyse how over the course of its history Apple became so profitable, they argue that there is no economic justification from a risk-reward perspective for this distribution to Apple's shareholders. Taxpayers and workers have superior claims on these profits. Vranceanu (2014) assesses that large firms manage to deliver positive profits even in the most competitive environments. They can do so, thanks to internal entrepreneurs, a subset of their employees able to drive change and develop innovation in the workplace. Krech et al. (2015, 2018) map profiting from the invention. Authors identify four groups of patent aggregating companies based on the profits provided to the original patent holders: the guarders, the shielders, the funders and the earners. Hu et al. (2017) differentiate technological leaders and latecomers. Their results demonstrate that innovations affect the profits of technological leaders as well as latecomers in different ways resulting in a relationship where the two play complementary roles. The study of Kim et al. (2019) try to ensure the genuine causality of profit and also it turns out practically useful. This paper develops a business model schema as a holistic two-dimensions multi-level tool/ method for business model innovation based on the direct causal mechanisms of profit. Bogliacino and Pianta (2012) firstly, invest the ability of industries' R\&D efforts to turn out successful innovations and secondly, the ability of innovations to lead to high profits and Janoskova and Kral (2019) mark innovative activity as an important source of competitiveness. Li et al. (2010) warn against R\&D blindness because of the fact that innovating firms sometimes fail to obtain profits from product innovation. The multiple-case study of Garst et al. (2017) investigates the connecting motive of the responsibility besides the motive of the probability of the firms for product innovation. Their study highlights the importance of having both profit and moral motives in the innovation process when aiming for socially responsible outcomes, and how both these motives contribute and interact.

\subsection{Corporate Social Responsibility or Not?}

Successful global companies in the 21st century have no doubts about the need to be socially responsible and developing a number of diverse activities that are involved in improving the business condition (Moravcikova \& Krizanova, 2016). One common justification for the pursuit of profit by business firms within a market economy is that profit is not an end in itself but a mean to produce and allocate resources more efficiently (Smith, 2018). Jeon et al. (2020) argue with Jones (1995) that corporate social responsibility can contribute to a company's profits through the favourable influence of corporate social responsibility initiatives on its relationships with its stakeholders. This economic dimension is also included in Corporate Social Performance model proposed by Carrol (1979) and extended by Carrol (1998). Presented economic dimension explains generating profits for stakeholders, creating jobs, and promoting the creation of innovative services and products. Friedman (1970) highlights that the only social responsibility of business is to increase its profits. Mulligan (1986) deals with a critique of Friedman essay that the social responsibility of business is to increase its profits. Freeman (1984) provides a more inclusive stakeholder perspective. McWilliams and Siegel (2001a) create a model of profit-maximizing corporate social responsibility demonstrating that common ground exists between Friedman's agency theory perspective (shareholders only) and Freeman's more inclusive stakeholder perspective. They clarify some misconceptions regarding their model (McWilliams \& Siegel, $2001 \mathrm{~b}$ ). If managers engage in the types of corporate social responsibility they identify, managers simultaneously satisfy shareholders and other primary stakeholders (i.e. consumers). Profit-maximizing corporate social responsibility also allows reconciling the conflicting empirical evidence of the impact of corporate social responsibility on financial performance (McWilliams \& Siegel, 1997, 2000). Their model specifically demonstrates that, in equilibrium, 
corporate social responsibility should have a neutral impact on performance. Furthermore, a model of profit-maximizing corporate social responsibility allows assessing the strategic implications of corporate social responsibility (Siegel, 2001). McWilliams et al. (2006) describe a variety of perspectives on corporate social responsibility, which they use to develop a framework for consideration of the strategic implications of corporate social responsibility. Blomgren (2011) investigates the relationship between corporate social responsibility and profits while avoiding the most important methodological pitfalls of the quantitative research and acknowledging the distinction between corporate social responsibility as a strategy for achieving average profits and as a strategy for achieving above-average profits. Socially responsible activities help create business profit, develop strategic resources, and insure against risks, but on the other hand, also cost money and distract management (Wang \& Bansal, 2012). Gil Salmerón (2016) questions: Can the most responsible companies be more profitable? His study proves the higher level of corporate social responsibility used, the more profitable the companies are. These conclusions are determined from a linear regression analysis comparing the Return on Assets. The redistribution of part of business profit to the employees is a credible commitment on the part of companies to allow their employees to participate in any efficiency gain. The employees are motivated to share their specific information advantage on possibilities to optimize the production process and products with the management (Aerts, Kraft, \& Lang, 2015). The survey of Krizanova et al. (2016) has shown that for employees, it is important to work for a socially responsible employer. Satisfied employees significantly contribute to the strengthening of the business profit.

\section{Materials and Research Methodology}

The secondary sources are observations of earnings before interest, taxes, depreciation and amortization (EBITDA) of Visegrad Four's enterprises. 1,347 Slovak enterprises, 859 Czech enterprises, 2,554 Polish enterprises and 880 Hungarian enterprises were extracted from the Amadeus database (provided by Moody's analytics company Bureau van Dijk) capturing years 2010 to 2018 . The variable
EBITDA is chosen to eliminate different tax, interest and depreciation policies of these emerging countries. The enterprises have to meet three set criteria: the value of total assets at the minimal level of 3,000,000 EUR; the value of total sales at the minimal level of 2,000,000 EUR; the value of net income at least 100,000 EUR. These criteria were applied to recognize only the financial stable enterprises and to analyse business entities of the same economic and financial background to mitigate the problems of the classification by size, year of operation or turnover achieved. In the research, a purposive sampling was used, thus the sample of enterprise is considered representative. Purposive sampling is a sampling technique in which researcher relies on their own judgment when choosing members of population to participate in the study (e.g. Singh \& Masaku, 2014). This type of sampling can be very useful in situations when there is a need to reach a targeted sample quickly, and where sampling for proportionality is not the main concern.

Following methodological steps were used:

1. The detection of outliers: Genuine outliers are typically treated in one of the following ways: keep the outlier and treat it like any other data point, winsorise it or eliminate it (Ghosh \& Vogt, 2012). The winsorising and eliminating introduce statistical bias and may undervalue the outlier, while keeping it and treating it like the other points may overvalue it and cause the estimate to vary drastically from the true population value (Ghosh \& Vogt, 2012). We prefer robust statistics and results insensitive to outliers, we decided for the third choice to drop all outliers from the sample.

Different techniques and tests exist to determine if some observations are outliers. Some visual methods are frequently used as a boxplot or adjusted boxplot. Z-scores are very popular method for labelling outliers (Garcia, 2012). The problem with Z-score may occur in a small data set, because of affecting the mean and the standard deviation by outliers and it is necessary to modify Z-score. We choose Z-score to detect outliers in this research. Our research contains great/huge samples from all the countries of the Visegrad Four that is way we may use not modified Z-score.

Nevertheless, it would be dangerous to blindly accept the result of only one technique without the judgment of another expert method (Garcia, 2012) we may support Z-score by 
another test used to detect outliers. ShapiroWilk W test is quite widely used but Cochran test, Dixon test and Grubbs test provide better results in identification. Cochran test detects crude errors. It is designed based on simple statistics - the ratio of maximum (or minimum) variance to the sum of all variances (Komsta, 2006). Simple statistics was already used in Z-score, more sophisticated approach is needed. Garcia (2012) discusses the possibility of the occurrence of the situations of additional outliers by Dixon test. We must minimize the effect of outliers, thus we decided to support Z-score by Grubbs test. Grubbs test detects one outlier at a time assuming a normal distribution. This outlier is expunged from the dataset and the test is iterated until no outliers are detected. Testing if the minimum or maximum values are outliers or testing of two opposite outliers are possibilities of Grubbs test (Garcia, 2012). First test was selected and also Garcia (2012) notes that this test is also called Modified Thomson Tau or the maximum normed residual test.

2. The normality proving: Normality is often a maintained assumption in estimation and finitesample inference (Bai \& Ng, 2012). Basically, normality is checked using $Q-Q$ plot, histogram, boxplot and steam-and-leaf-plot. These graphical methods are supported by numerical methods as a skewness and kurtosis. Formal normality test should be performed before any conclusion about the normality of the data. There are nearly 40 tests of normality in statistical literature (Dufour et al., 1998). The tests in question are e.g. Chi-squared, Kolmogorov-Smirnov, AndersonDarling, Kuiper, Shapiro-Wilk, Ajne, modified Ajne, modified Kuiper, D'Agostino, modified Kolmogorov-Smirnov, Lilliefors test, Vasicek, and Jarque-Bera tests, etc (Yazici \& Yolacan, 2007; Razali \& Wah, 2011). Bai and Ng (2005) recommend to test the normality of time series data by Jarque-Bera test. We supported this test by Shapiro-Wilk W test, Anderson-Darling test, Lilliefors test. Shapiro and Wilk (1965) test was originally restricted for sample of less than 50 observations. Chen (1971) highlights the power of the Shapiro-Wilk W statistic demonstrated favourable sensitivity in testing normality under different contaminated normal distributions. Lilliefors test is a modification of the KolmogorovSmirnov test. It is preferred in the cases when it is difficult to initially or completely specify the parameters as the distribution is unknown, which is typical of our research. Grubbs test focuses on outliers from the minimum or maximum values and we complementary performed AndersonDarling test (modification of the Cramer-von Mises test) to give more weights to the tails of distribution by proving normality (Farrell \& Rogers-Stewart, 2006; Razali \& Wah, 2011). We do not also verify the constant variance over time because of the period of time series is very short.

3. The indication of independency distribution: The occurrence of the autocorrelation means that the data are not independently distributed. The Box-Pierce and Ljung-Box tests are portmanteau tests generally used to test the independence in time series data. These tests can also be applied to the squares of the observations to detect independence (Warriyar et al., 2016). Box and Pierce (1970) perform test of the randomness at each distinct lag in their study. Ljung and Box (1978) modify this test to overall randomness. We prefer the robustness of the Box-Pierce statistic to test if the finite-sample performance of financial time series is uncorrelated without assuming statistical independence.

4. The detection of homogeneity: Homogeneity tests enable to determine if time series may be considered as homogeneous over time, or if there is any point (in our case a year) at which a change occurs. Many methods have been proposed to test the homogeneity. We prefer nonparametric tests in our case of annual data that are robust to large data gaps (Meals et al., 2011). Kanovsky (2018) and Agha et al. (2017) recommend to select from Standard Normal Homogeneity test (SNHT), Buishand test (BR), Von Neumann (VNR) and Pettitt's test. We run Pettitt's test using 10,000 Monte Carlo simulations to test homogeneity because of this test is the non-parametric rank test that can reveal the single break point (month or year) at a continuous data (Pettitt, 1979). According to Pohlert (2020), Pettitt's tests the $H_{0}$ : The $T$ variables follow one or more distributions that have the same location parameter (no change), against the alternative: A change point exists. The non-parametric statistic is defined as:

$$
K_{T}=\max \left|U_{t, T}\right|
$$

where:

$$
U_{t, T}=\sum_{\mathrm{i}=1}^{t} \sum_{\mathrm{j}=\mathrm{t}+1}^{T} \operatorname{sgn}\left(X_{i}-X_{j}\right)
$$




\section{Business Administration and Management}

The change-point of the series is located at $K_{T}$, provided that the statistic is significant. The significance probability of $K_{T}$ is approximated for $p$-value $\leq 0.05$ with:

$$
p \cong 2 \exp \left(\frac{-6 K_{t}^{2}}{T^{3}+T^{2}}\right)
$$

The analysis allows us to formulate the following hypotheses which are verified at the significance level alpha 0.05:

Hypothesis $_{1 A-D}$ : There is a date at which a change in the data of EBITDA of Slovak, Czech, Polish and Hungarian enterprises occurred.

\section{Research Results}

The first point of the research is to identify an amount and the existence of missing values in origin sample and remove them. After removal of incomplete data, the subsequent evaluation of the existence of outliers in observations of EBITDA of Slovak, Czech, Polish and
Hungarian enterprises is realized by Z-score and verified by Grubbs test. Their occurrence in the sample could cause changes in the results of statistical tests and procedures (Svabova \& Durica, 2019).

$H_{0}$ : There is no outlier in the data of EBITDA.

$H_{1}$ : There is at least one outlier in the data of EBITDA.

As the computed $p$-value is lower than the significance level alpha, one should reject the null hypothesis $H_{0}$, and accept the alternative hypothesis $H_{1}$, based on Tab. 1. There is at least one outlier in the observations of EBITDA. This situation happened for all of the countries of Visegrad Four.

The existence of missing values and outliers caused the reduction of origin subsamples in all cases (Tab. 2). Together 289 missing values and outliers were identified in the Slovak sample; 171 in the Czech subsamples, the biggest reduction was in Polish observations ( 1,178 cases) and 149 in Hungary.

\section{Tab. 1: Grubbs test}

\begin{tabular}{l|c|c|c|c}
\multicolumn{1}{c|}{ Grubbs test } & Slovakia & Czechia & Poland & Hungary \\
\hline $\mathrm{G}$ (Observed value) & 23.298 & 24.187 & 35.059 & 27.116 \\
\hline $\mathrm{G}$ (Critical value) & 4.076 & 3.952 & 4.131 & 3.970 \\
\hline P-value (Two-tailed) & $<\mathbf{0 . 0 0 0 1}$ & $<\mathbf{0 . 0 0 0 1}$ & $<\mathbf{0 . 0 0 0 1}$ & $<\mathbf{0 . 0 0 0 1}$ \\
\hline
\end{tabular}

Source: own

\section{Tab. 2: Numbers of observations}

\begin{tabular}{l|c|c|c|c}
\multicolumn{1}{c|}{ Samples } & Slovakia & Czechia & Poland & Hungary \\
\hline Origin & 1,347 & 859 & 2,554 & 880 \\
\hline Outliers & 289 & 171 & 1,178 & 149 \\
\hline Final & $\mathbf{1 , 0 5 8}$ & $\mathbf{6 8 8}$ & $\mathbf{1 , 3 7 6}$ & $\mathbf{7 3 1}$ \\
\hline
\end{tabular}

Source: own

Based on annual results of earnings before interest, taxes, depreciation and amortization of 1,058 Slovak enterprises, 688 Czech enterprises, 1,376 Polish enterprises and 731 Hungarian enterprises the last step was constructed considering the data preparation and it is the calculation of and annual average of Visegrad group's enterprises during the analysed nine-year period (Tab. 3).

To provide reliability, robustness and consistency of the results, it is necessary to prove normality. For the importance of this analytical step, four normality tests were run to ensure the quality of the results: Jarque-Bera 


\section{Tab. 3: Average EBITDA [thousands EUR]}

\begin{tabular}{l|c|c|c|c}
\multicolumn{1}{c|}{ Year } & Slovakia & Czechia & Poland & Hungary \\
\hline 2010 & $1,471.379$ & $4,526.141$ & $1,534.720$ & $1,410.031$ \\
\hline 2011 & $1,499.398$ & $4,649.366$ & $1,531.875$ & $1,430.479$ \\
\hline 2012 & $1,505.252$ & $4,904.937$ & $1,609.707$ & $1,554.215$ \\
\hline 2013 & $1,551.384$ & $4,645.056$ & $1,753.624$ & $1,857.260$ \\
\hline 2014 & $1,738.280$ & $5,031.779$ & $1,900.449$ & $2,084.514$ \\
\hline 2015 & $1,917.288$ & $5,458.817$ & $2,083.086$ & $2,365.801$ \\
\hline 2016 & $2,046.715$ & $5,564.691$ & $2,213.171$ & $2,614.866$ \\
\hline 2017 & $2,132.926$ & $5,949.365$ & $2,448.194$ & $2,836.100$ \\
\hline
\end{tabular}

Source: own

\section{Tab. 4: Normality tests}

\begin{tabular}{l|c|c|c|c}
\multicolumn{1}{c|}{ Test/Country } & Slovakia & Czechia & Poland & Hungary \\
\hline Jarque-Bera test (Two-tailed) & 0.589 & 0.638 & 0.662 & 0.670 \\
\hline Shapiro-Wilk test (Two-tailed) & 0.111 & 0.217 & 0.326 & 0.419 \\
\hline Jarque-Bera test (Two-tailed) & 0.145 & 0.301 & 0.487 & 0.563 \\
\hline Lilliefors test (Two-tailed) & 0.182 & 0.684 & 0.809 & 0.730 \\
\hline
\end{tabular}

Source: own

test, Shapiro-Wilk test, Anderson-Darling test and last but not least Lilliefors test.

$H_{0}$ : The variable which the sample was extracted from follows a normal distribution.

$H_{1}$ : The variable which the sample was extracted from does not follow a normal distribution.

Running of four tests of normality proving is realized because each test has its own importance for the analysis. Firstly, we use the Lilliefors test because the distribution is unknown, and it is difficult to specify the parameters initially. Secondly, our sample consists of a nine-year period that is why we have to use Shapiro-Wilk test given for the sample that involves less than 50 observations. Thirdly, it is necessary to focus on the tails of distribution and it is proved by the AndersonDarling test. Finally, we highlight the financial data of EBITDA in the time period and considering this fact, the Jarque-Bera test is recommended for time series modelling.

As the computed p-value is greater than the significance level alpha, one cannot reject the null hypothesis $H_{0}$, based on Tab. 4 . The hypothesis that average Slovak, Czech, Polish and Hungarian earnings before interest, taxes, depreciation and amortization are normally distributed was not rejected for all cases as well as all tests.

After proving normality, one more statistical testing is to be done before searching the year of change in time series of EBITDA. We must confirm independency of distribution, it means, that there is no serial correlation in subsamples. This randomness of the sampling process is verified by Box-Pierce test.

$H_{0}$ : The data are independently distributed (the correlations in the population which the sample is taken from are zero, so that any observed correlations in the data result from the randomness of the sampling process).

$H_{1}$ : The data are not independently distributed (they exhibit serial correlation).

As the computed $p$-value is greater than the significance level alpha, one cannot reject the null hypothesis $H_{0}$, based on Tab. 5. The hypothesis that average Slovak, Czech, Polish 


\section{Tab. 5: Box-Pierce test}

\begin{tabular}{l|c|c|c|c}
\multicolumn{1}{c|}{ Box-Pierce test } & Slovakia & Czechia & Poland & Hungary \\
\hline Value & 10.570 & 8.287 & 9.228 & 9.500 \\
\hline P-value (Two-tailed) & $\mathbf{0 . 1 0 3}$ & $\mathbf{0 . 2 1 8}$ & $\mathbf{0 . 1 6 1}$ & $\mathbf{0 . 1 4 7}$ \\
\hline
\end{tabular}

Source: own

and Hungarian earnings before interest, taxes, depreciation and amortization are independently distributed was not rejected.

Finally, we tested the hypotheses to achieve the main aim of the paper. All of them are related to the detection of the existence of the "change-point" in EBITDA of Visegrad countries. Hypotheses were tested by Pettitt's test using 10,000 Monte Carlo simulations.

$H_{0}$ : Data of EBITDA are homogeneous.

Hypothesis $_{1 \mathrm{~A}}$ : There is a date at which a change in the data of EBITDA of Slovak enterprises occurred.

Hypothesis $_{1 \mathrm{~B}}$ : There is a date at which a change in the data of EBITDA of Czech enterprises occurred.

Hypothesis $_{1 \mathrm{C}}$ : There is a date at which a change in the data of EBITDA of Polish enterprises occurred.

Hypothesis $_{10}$ : There is a date at which a change in the data of EBITDA of Hungarian enterprises occurred.

As the computed p-value is lower than the significance level alpha, one should reject the null hypothesis $H_{0}$, and accept the alternative hypothesis $H_{1}$, based on Tab. 6 . There is one year at which there is a change in the data of EBITDA. This is confirmed for all of the countries of Visegrad Four. The Pettitt's test not only detected the occurrence of the changepoints of EBITDA and also set the year that was significant in the development of EBITDA of Slovak, Czech, Polish and Hungarian enterprises. Surprisingly identified fact of our result is that all the countries have the same significant year. It is the year 2013, what is supported and demonstrated on Fig. 1. This year divides the development of the business profit into two homogeneous series, which values of the central lines are also shown. Identified significant year caused the positive change in monotonic development of time series of EBITDA. We might argue, based on our research that despite the fact that the countries are not in one bloc of controlled countries for three decades, but the influence is still so strong that the developments of Slovakia, Czechia, Poland and Hungary vary, but the final result is uniform.

Fig. 1 does not only involve the indicated year 2013; this year divides the development of the business profit into two homogeneous series, which values of the central lines are also shown. The level of set central lines is 1,507,000 EUR to 2013 and 2,005,000 EUR for Slovak enterprises since 2013. The difference is 490,000 EUR between these fictionally calculated periods of development of EBITDA. In the Czech enterprises, the level of calculated central lines is 4,681,000 EUR to 2013 and 5,592,000 EUR since 2013. The difference between these calculated periods

\section{Tab. 6: Pettitt's test}

\begin{tabular}{l|c|c|c|c}
\multicolumn{1}{c|}{ Pettitt's test } & Slovakia & Czechia & Poland & Hungary \\
\hline $\mathrm{K}_{\mathrm{T}}$ & 20.000 & 20.000 & 20.000 & 20.000 \\
\hline $\mathrm{t}$ (significant change-point) & 2013 & 2013 & 2013 & 2013 \\
\hline $\mathrm{mu}_{1}$ [thousand EUR] & 1,507 & 4,681 & 1,607 & 1,563 \\
\hline $\mathrm{mu}_{2}$ [thousand EUR] & 2,005 & 5,592 & 2,236 & 2,587 \\
\hline $\mathrm{P}$-value (Two-tailed) & $<0.0001$ & $<0.0001$ & $<0.0001$ & $<0.0001$ \\
\hline
\end{tabular}




\section{Fig. 1: Change-points in Visegrad Four}

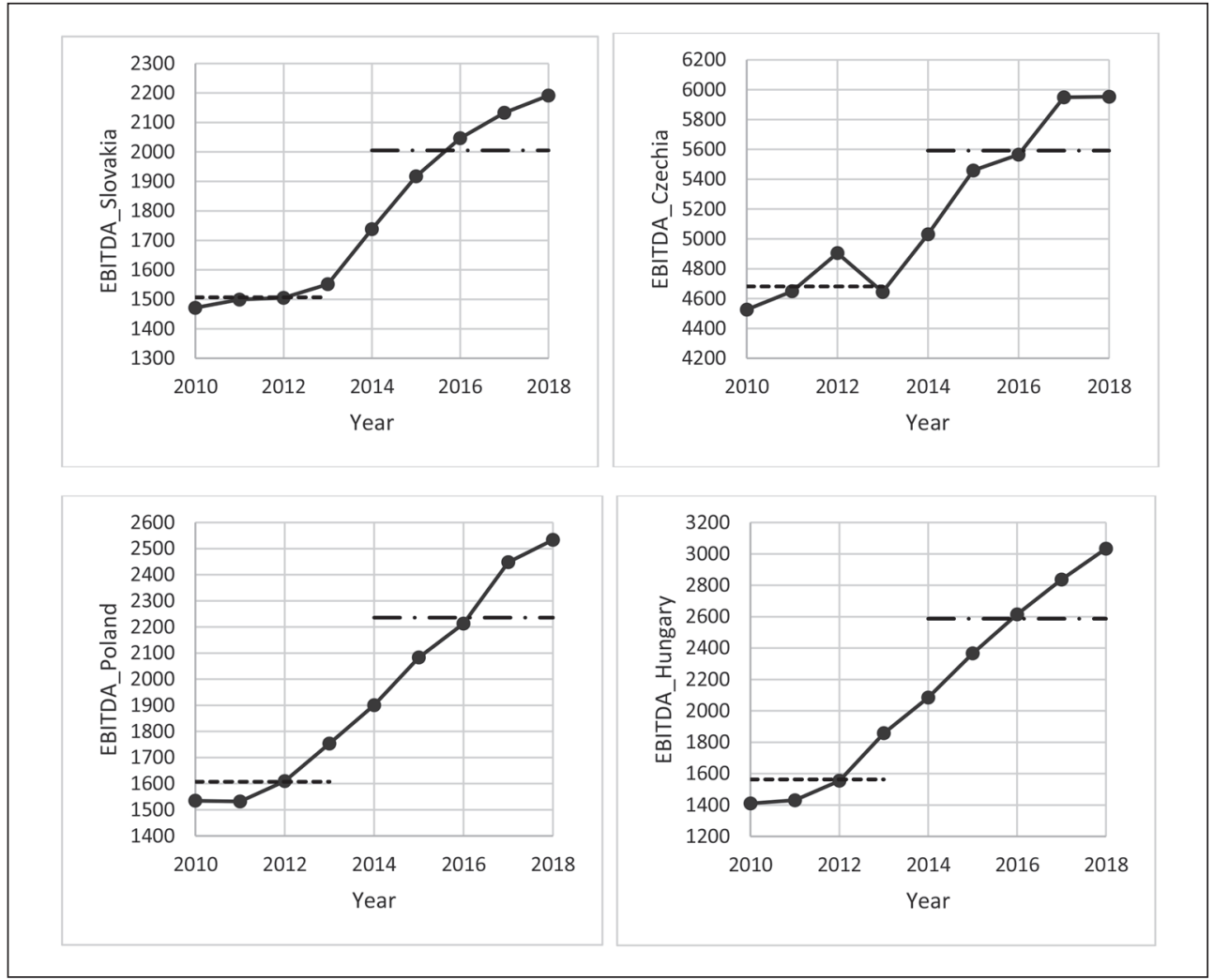

Source: own

Note: Dotted line EBITDA, dashed line $\mathrm{mu}_{1}$, dash-dotted line $\mathrm{mu}_{2}$.

of development of EBITDA is 911,000 EUR. In Poland, the level of set central lines is $1,607,000$ EUR to 2013 and 2,236,000 EUR since 2013. The difference means 629,000 EUR between these fictionally calculated periods of the EBITDA development. The level of calculated central lines in Hungary is $1,563,000$ EUR to 2013 and 2,587,000 EUR since 2013. The difference means $1,024,000$ EUR. All the indicated differences in central lines oscillate from 490,000 EUR to 1,024,000 EUR, which does not reveal big discrepancies within the enterprises from our purposive sample and confirm that the same year 2013 was significant for the EBITDA developments but also the level of changes expressed in absolute values is approximately uniform.

\section{Discussion}

We discuss our presented results related to the business profit in Visegrad Group (every changepoints in times series of EBITDA is detected in 2013) to the areas and factors that could affect them. We consider the development in these four countries as very similar (alternative but with the equal nature of the result). Schwab (2014) placed Slovakia, Hungary and Poland in the stage of development to the stage of Transition from stage 2 (Efficiency-driven) to stage 3 (Innovation-driven) and Czechia to stage 3 . We support our discussion by data from the global competitiveness reports from 2010 to 2019 from World Economic Forum and EuroStat. Lemańska-Majdzik and Okręglicka (2015) select based on comprehensive 


\section{Business Administration and Management}

Tab. 7:

Pettitt's test of Adjustable area and Uncontrollable macroeconomic factors

\begin{tabular}{|c|c|c|c|c|}
\hline & Slovakia & Czechia & Poland & Hungary \\
\hline \multicolumn{5}{|c|}{ Business dynamism } \\
\hline $\mathrm{K}_{\mathrm{T}}$ & 17 & 14 & 16 & 8 \\
\hline t (significant change-point) & - & - & - & - \\
\hline $\mathrm{mu}$ & 59.444 & 33.667 & 60.222 & 87.333 \\
\hline P-value (Two-tailed) & 0.117 & 0.346 & 0.529 & 0.17 \\
\hline \multicolumn{5}{|c|}{ GDP } \\
\hline $\mathrm{K}_{\mathrm{T}}$ & 20.000 & 20.000 & 20.000 & 20.000 \\
\hline $\mathrm{t}$ (significant change-point) & 2013 & 2013 & 2013 & 2013 \\
\hline mu $_{1}$ [million EUR] & 71,269 & 159,984 & 381,539 & 100,384 \\
\hline $\mathrm{mu}_{2}$ [million EUR] & 82,301 & 181,724 & 446,353 & 117,267 \\
\hline P-value (Two-tailed) & $<0.0001$ & $<0.0001$ & $<0.0001$ & $<0.0001$ \\
\hline \multicolumn{5}{|c|}{ Unemployment rate } \\
\hline $\mathrm{K}_{\mathrm{T}}$ & 20.000 & 20.000 & 20.000 & 20.000 \\
\hline t (significant change-point) & 2013 & 2013 & 2013 & 2013 \\
\hline $\mathrm{mu}_{1}[\%]$ & 14.1 & 7 & 9.95 & 10.85 \\
\hline $\mathrm{mu}_{2}[\%]$ & 9.8 & 4.06 & 6.3 & 5.5 \\
\hline P-value (Two-tailed) & $<0.0001$ & $<0.0001$ & $<0.0001$ & $<0.0001$ \\
\hline \multicolumn{5}{|c|}{ Inflation rate } \\
\hline $\mathrm{K}_{\mathrm{T}}$ & 20.000 & 20.000 & 20.000 & 20.000 \\
\hline t (significant change-point) & 2013 & 2013 & 2013 & 2013 \\
\hline $\mathrm{mu}_{1}[\%]$ & 2.5 & 2.325 & 2.3 & 4.25 \\
\hline $\mathrm{mu}_{2}[\%]$ & 0 & 1.14 & 0.42 & 1.16 \\
\hline P-value (Two-tailed) & $<0.0001$ & $<0.0001$ & $<0.0001$ & $<0.0001$ \\
\hline \multicolumn{5}{|c|}{ Average monthly gross wage } \\
\hline $\mathrm{K}_{\mathrm{T}}$ & 20.000 & 20.000 & 20.000 & 20.000 \\
\hline t (significant change-point) & 2013 & 2013 & 2013 & 2013 \\
\hline $\mathrm{mu}_{1}[E U R]$ & 796 & 965 & 889.75 & 761.5 \\
\hline $\mathrm{mu}_{2}$ [EUR] & 924 & 1,081 & 1,026 & 898.2 \\
\hline P-value (Two-tailed) & $<0.0001$ & $<0.0001$ & $<0.0001$ & $<0.0001$ \\
\hline \multicolumn{5}{|c|}{ Ease of doing business index } \\
\hline $\mathrm{K}_{\mathrm{T}}$ & 20.000 & 20.000 & 20.000 & 20.000 \\
\hline t (significant change-point) & 2013 & 2013 & 2013 & 2013 \\
\hline $\mathrm{mu}_{1}$ & 45.75 & 69.25 & 53.5 & 56.5 \\
\hline $\mathrm{mu}_{2}$ & 34.6 & 30.2 & 27.4 & 43.6 \\
\hline P-value (Two-tailed) & $<0.0001$ & $<0.0001$ & $<0.0001$ & $<0.0001$ \\
\hline
\end{tabular}


literature review factors most affecting success of the enterprises: type and size, profile of business activity conducted, character of the environment, economic cooperation on the market, adopted strategy of action, implementation of innovation and new technologies, staff satisfied with their jobs, competent leader. They argue that it is only fragment of a long list affected factors that is why we divide the list to the adjustable area and uncontrollable macroeconomic factors from the side of the enterprises. We confirm that both have the influence but the question is: Do they both have significant impact on the business profit characterised by EBITDA? We focus a priory on: (i) adjustable area by the enterprises that represents business dynamism; one of the crucial pillars of the global competitiveness index. It includes: cost of starting a business, time to start a business day, insolvency recovery rate, insolvency regulatory framework, attitudes toward entrepreneurial risk, willingness to delegate authority, growth of innovative companies, companies embracing disruptive ideas (Schwab, 2019); (ii) uncontrollable macroeconomic factors that represent GDP, unemployment rate, inflation rate, average monthly gross wage, and Ease of doing business index.

\section{$H_{0}$ : Data are homogeneous.}

$H_{1}$ : There is a date at which there is a change in the data.

As in previous part, we run Pettitt's test using 10,000 Monte Carlo simulations to test hypotheses.

As the computed $p$-value is greater than the significance level alpha, one cannot reject the null hypothesis $H_{0}$, based on Tab. 7 . There are no years where a change in the data occurred. This situation is unveiled when testing the influence of the business dynamism on EBITDA.

As the computed $p$-value is lower than the significance level alpha, one should reject the null hypothesis $H_{0}$, and accept the alternative hypothesis $H_{1}$, based on Tab. 10. There are significant years where there is a significant change in the data. This situation occurs by all of uncontrollable macroeconomic factors, and the results indicate that for all considered macroeconomic factors the most significant changes happened in 2013. We argue based on our results and the discussion that the change-point of positive monotonic development of EBITDA was not significantly caused by adjustable area, but it was definitely confirmed and demonstrated by uncontrollable macroeconomic factors that the impact of them on the business profit represented by EBITDA is inalienable. The significant change of the monotonic development of EBITDA was positive since the year 2013, which is supported and corresponded with the significant growth of GDP, significant decrease of the unemployment rate, significant decrease of the inflation rate, significant growth of an average monthly gross wage and significant improvement of the Ease of doing business index in all countries of the Visegrad Four. This fact is confirmed by comparing the levels of identified central lines of chosen uncontrollable macroeconomic indicators from Tab. 7.

A limitation of our research is perceived by the focus of the research on the chosen factors affected the results related to the business profit, the research does not take into account the influences of macroeconomic factors as producer prices change, foreign direct investment, business confidence, etc. Another limitation might be the omission of the use of parametric tests that are considered more powerful and/or sensitive than nonparametric tests to detect significant trends, especially with a small sample number (Meals et al., 2011).

We consider the following areas as potential directions for further progress in the research: supporting results revealing the change point in times series of EBITDA by the use of SNHT test, Buishand's test and von Neumann's test; a completing of this case study in Sovietcontrolled Eastern bloc counties to add Romanian results; an extension of the areas of the interest to formerly parts of the Soviet Union: Russia, Belarus, Ukraine, Estonia, Latvia, and Lithuania; an indication of trend existence in times series of EBITDA by MannKendall trend test and Sen's slope as well as time series decomposition.

\section{Conclusions}

The objective of all business activities in a market environment is the long-term economic prosperity of business entities, which is determined by business profitability. The profit is considered to be the starting point for all other factors and an indispensable financial indicator that expresses the success and efficiency of business, especially in the relation to the invested capital. It is necessary for the enterprises to know which period of their business life was the break one considering the 
business finance. Moreover, it is important also for the country represented by the government because it has the great chance to support enterprises to be successful by creating fair, positive and open competitive environment.

This research has several useful contributions. Firstly, it is the identification of the break point (year 2013), which indicates the significant change in the profit development, caused not only by the corporate development itself but also as a consequence of macroeconomic development in the countries. Secondly, the evidence was provided that enterprises in the Visegrad countries tend to manipulate earnings, and thus the importance of further research is unquestionable. This study provides important insights for state authorities, policymakers, auditors, consulting and accounting enterprises to develop possible measures and identify earnings management techniques and try to protect the market, banks, stakeholders and creditors from financial risks caused by distorted financial reports.

Acknowledgement: This paper was supported by the Slovak Research and Development Agency under Grant number APVV-17-0546: Variant Comprehensive Model of Earnings Management in Conditions of the Slovak Republic as an Essential Instrument of Market Uncertainty Reduction.

\section{References}

Aerts, K., Kraft, K., \& Lang, J. (2015). Profit sharing and innovation. Industrial and Corporate Change, 24(6), 1377-1392. https://doi.org/10.1093/icc/dtv009

Agha, O. M. A. M., Bağçacı, S. Ç., \& Şarlak, N. (2017). Homogeneity analysis of precipitation series in North Iraq. IOSR Journal of Applied Geology and Geophysics, 5(3), 57-63. https:// doi.org/10.9790/0990-0503025763

Altman, J., \& Dillon, M. (2005). Commercial development and natural resource management on the indigenous estate: A profit-related investment proposal. Economic Papers: A Journal of Applied Economics and Policy, 24(3), 249-262. https://doi. org/10.1111/j.1759-3441.2005.tb00377.x

Anand, A., Singhal, S., \& Singh, $O$. (2019). Optimal advertising duration for profit maximization. Journal of Management Analytics, 1-23. https://doi.org/10.1080/23270 012.2019.1702904
Anderson, S. J., Chandy, R., \& Zia, B. (2018). Pathways to profits: The impact of marketing vs. finance skills on business performance. Management Science, 64(12), 5559-5583. https://doi.org/10.1287/mnsc.2017.2920

Angelova, G., Parvanov, P., Chetrafilov, G., Krasteva, N. Y., \& Krastev, V. I. (2017). Sustainability in tourism cadre training and selection in Bulgaria perceptions of university students on their skills. REVISTA INCLUSIONES, 4(3), 144-156.

Aram, J. D., \& Cowen, S. S. (1990). Strategic planning for increased profit in the small business. Long Range Planning, 23(6), 63-70. https://doi.org/10.1016/0024-6301(90)90103-B

Bai, J., \& Ng, S. (2005). Tests for skewness, kurtosis, and normality for time series data. Journal of Business \& Economic Statistics, 23(1), 49-60. https://doi. org/10.1198/073500104000000271

Belás, J., \& Sopková, G. (2016). A Model of Entrepreneurial Orientation. Transformation in Business \& Economics, 15(2), 630-644.

Blomgren, A. (2011). Does corporate social responsibility influence profit margins? A case study of executive perceptions. Corporate Social Responsibility and Environmental Management, 18(5), 263-274. https://doi. org/10.1002/csr.246

Bogliacino, F., \& Pianta, M. (2012). Profits, R\&D, and innovation - A model and a test. Industrial and Corporate Change, 22(3), 649678. https://doi.org/10.1093/icc/dts028

Box, G. E., \& Pierce, D. A. (1970). Distribution of residual autocorrelations in autoregressive-integrated moving average time series models. Journal of the American Statistical Association, 65(332), 1509-1526. https://doi.org/10.2307/2284333

Capponi, G., Criscuolo, P., Martinelli, A., \& Nuvolari, A. (2019). Profiting from innovation: Evidence from a survey of Queen's Awards winners. Structural Change and Economic Dynamics, 49, 155-169. https://doi. org/10.1016/j.strueco.2019.02.002

Carroll, A. B. (1979). A three-dimensional conceptual model of corporate performance. Academy of management review, 4(4), 497505. https://doi.org/10.5465/amr.1979.4498296

Carroll, A. B. (1998). The four faces of corporate citizenship. Business and society review, 100/101(1), 1-7. https://doi. org/10.1111/0045-3609.00008 
Chen, E. H. (1971). The power of the Shapiro-Wilk W test for normality in samples from contaminated normal distributions. Journal of the American Statistical Association, 66(336), 760-762. https://doi.org/10.1080/0162 1459.1971.10482342

Chuang, C.-J., \& Wu, C.-W. (2019). Determining optimal process mean and quality improvement in a profit-maximization supply chain model. Quality Technology \& Quantitative Management, 16(2), 154-169. https://doi.org/1 $0.1080 / 16843703.2017 .1389124$

Desyllas, P., \& Sako, M. (2013). Profiting from business model innovation: Evidence from Pay-As-You-Drive auto insurance. Research Policy, 42(1), 101-116. https://doi.org/10.1016/j. respol.2012.05.008

Dufour, J.-M., Farhat, A., Gardiol, L., \& Khalaf, L. (1998). Simulation-based Finite Sample Normality Tests in Linear Regressions. Econometrics Journal, 1(1), 154-173. https://doi.org/10.1111/1368-423X.11009

Farrell, P. J., \& Rogers-Stewart, K. (2006). Comprehensive study of tests for normality and symmetry: extending the Spiegelhalter test. Journal of Statistical Computation and Simulation, 76(9), 803-816. https://doi. org/10.1080/10629360500109023

Felstead, M. (2019). Cyber-physical production systems in Industry 4.0: Smart factory performance, innovation-driven manufacturing process innovation, and sustainable supply chain networks. Economics, Management, and Financial Markets, 14(4), 37-43. https://doi. org/10.22381/EMFM14420195

Freeman, R. (1984). Strategic Management: A Stakeholder Perspective. Englewood Cliffs, $\mathrm{NJ}$ : Prentice-Hall.

Friedman, H. H., Friedman, L. W., Frankel, M. R., \& Amoo, T. (2019). Enhancing critical and ethical thinking with scenarios. Psychosociological Issues in Human Resource Management, 7(1), 7-29. https://doi. org/10.22381/PIHRM7120191

Friedman, M. (1970, September 13). The social responsibility of business is to increase its profits. The New York Times Magazine, pp. 122-126. https://doi.org/10.1007/978-3540-70818-6_14

Furnham, P. (2019). Automation and autonomy of big data-driven algorithmic decision-making. Contemporary Readings in Law and Social Justice, 11(1), 51-56. https://doi.org/10.22381/CRLSJ11120198
Garcia, F. A. A. (2012). Tests to Identify Outliers in Data Series (Doctoral dissertation). Rio de Janeiro: Pontifical Catholic University of Rio de Janeiro.

Garst, J., Blok, V., Jansen, L., \& Omta, O. (2017). Responsibility versus profit: The motives of food firms for healthy product innovation. Sustainability, 9(12), 2286. https://doi.org/10.3390/su9122286

Gazzola, P., Vătămănescu, E.-M., Andrei, A. G., \& Marrapodi, C. (2019). Users' motivations to participate in the sharing economy: Moving from profits toward sustainable development. Corporate Social Responsibility and Environmental Management, 26(4), 741-751. https://doi.org/10.1002/csr.1715

George, R., \& Kabir, R. (2008). Business groups and profit redistribution: $A$ boon or bane for firms? Journal of Business Research, 61(9), 1004-1014. https://doi.org/10.1016/j. jbusres.2007.12.002

Ghosh, D., \& Vogt, A. (2012). Outliers: An evaluation of methodologies. In JSM Proceedings, Survey Research Methods Section (pp. 34553460). Alexandria, VA: American Statistical Association. Retrieved from http://www.asasrms. org/Proceedings/y2012/Files/304068_72402.pdf

Ghosh, D., Ghosh, D. K., \& Zaher, A. A. (2011). Business, ethics, and profit: Are they compatible under corporate governance in our global economy? Global Finance Journal, 22(1), 72-79. https://doi.org/10.1016/j.gfj.2011.05.006

Gil Salmerón, A. M. (2016). The relationship of CSR and the business profit: can the most responsible companies be more profitable? Revista FIR, FAEDPYME International Review, 5(8), 60-71. Retrieved from http://faedpyme.ojs. upct.es/index.php/revista1/article/view/107/162

Hallberg, N. L., \& Brattström, A. (2019). Concealing or revealing? Alternative paths to profiting from innovation. European Management Journal, 37(2), 165-174. https://doi.org/10.1016/j.emj.2018.04.003

Hayhoe, T., Podhorská, I., Siekelová, A., \& Stehel, V. (2019). Sustainable manufacturing in Industry 4.0: Cross-sector networks of multiple supply chains, cyberphysical production systems, and Al-driven decision-making. Journal of Self-Governance and Management Economics, 7(2), 31-36. https://doi.org/10.22381/JSME7220195

Hu, M.-C., Kang, J.-S., \& Wu, C.-Y. (2017). Determinants of profiting from innovation activities: Comparisons between technological 
leaders and latecomers. Technological Forecasting and Social Change, 116, 223-236. https://doi.org/10.1016/j.techfore.2016.10.013

Hudakova, M., Masar, M., Luskova, M., \& Patak, M. R. (2018). The Dependence of Perceived Business Risks on the Size of SMEs. Journal of Competitiveness, 10(4), 54-69. https://doi.org/10.7441/joc.2018.04.04

Hussain, W. (2012). Corporations, profit maximization and the personal sphere. Economics \& Philosophy, 28(3), 311-331. https://doi.org/10.1017/S0266267112000260

Janoskova, K., \& Kral, P. (2019). An InDepth Analysis of the Summary Innovation Index in the V4 Countries. Journal of Competitiveness, 11(2), 68-83. https://doi. org/10.7441/joc.2019.02.05

Jensen, M. C. (2001). Value maximization, stakeholder theory, and the corporate objective function. Journal of Applied Corporate Finance, 14(3), 8-21. https://doi. org/10.1111/j.1745-6622.2001.tb00434.x

Jensen, M. C. (2002). Value maximization, stakeholder theory, and the corporate objective function. Business Ethics Quarterly, 12(2), 235-256. https://doi.org/10.2307/3857812

Jeon, M. M., Lee, S., \& Jeong, M. (2020). Perceived corporate social responsibility and customers' behaviors in the ridesharing service industry. International Journal of Hospitality Management, 84, 102341. https://doi.org/10.1016/j.ijhm.2019.102341

Jones, T. M. (1995). Instrumental stakeholder theory: A synthesis of ethics and economics. Academy of Management Review, 20(2), 404-437. https://doi.org/10.5465/ amr.1995.9507312924

Kamble, S. S., Gunasekaran, A., \& Gawankar, S. A. (2018). Industry 4.0 framework: A systematic literature review identifying the current trends and future perspectives. Process Safety and Environmental Protection, 117, 408-425. https://doi.org/10.1016/j. psep.2018.05.009

Kanovský, M. (2018). The Research Effectivity of Slovak Universities: Quantitative Analysis of Trends 2008-2017. Sociológia Slovak Sociological Review, 50(4), 429-447. https://doi.org/10.31577/sociologia.2018.50.4.17

Kim, I.-H. S., Ku, T.-Y. D., \& Lee, B.-Y. M. (2019). Business model schema: business model innovation tool based on direct causal mechanisms of profit. Technology Analysis \& Strategic Management, 32(4), 379-396. https://doi.org/10.1080/09537325.2019.1661988

Komsta, L. (2006). Processing data for outliers. The Newsletter of the R Project, 6(2), 10-14.

Kotek, K., Schoenberg, A. M., \& Schwand, C. (2018). CSR Behavior: Between Altruism and Profit Maximization. In R. Altenburger (Ed.), Innovation Management and Corporate Social Responsibility (pp. 159-169). Cham: Springer. https://doi.org/10.1007/978-3-319-93629-1_8

Kowo, A. S., Sabitu, O. O., \& Bola, K. (2019). An investigation of the role of entrepreneurship agencies for entrepreneurship development in Nigeria. Ekonomicko-manazerske Spektrum, 13(2), 68-80. http://dx.doi.org/10.26552/ ems.2019.2.68-80

Krastev, V., Koyundzhiyska-Davidkova, B., \& Atanasova, I. (2020). The impact of the corruption on the sustainable development of the businesses in South-West Bulgaria. In Proceedings of the 19th International Scientific Conference Globalization and its Socio-Economic Consequences 2019 - Sustainability in the Global-Knowledge Economy (SHS Web of Conferences Vol. 74, No. 06015). Rajecke Teplice, Slovakia. https://doi.org/10.1051/shsconf/20207406015

Krech, C. A., Rüther, F., \& Gassmann, O. (2015). Profiting from invention: Business models of patent aggregating companies. International Journal of Innovation Management, 19(03), 1540005. https://doi.org/10.1142/ S1363919615400058

Krech, C. A., Rüther, F., \& Gassmann, O. (2018). Profiting from invention: Business models of patent aggregating companies. In J. Tidd (Ed.), Exploiting Intellectual Property to Promote Innovation and Create Value (pp. 361-391). Singapur: World Scientific Publishing Company. https://doi.org/10.1142/9781786343512_0016

Kristofik, P., Horak, J., \& Suler, P. (2019). Provision of trade credits in relation to corporate payment ability: A case study of the Visegrad four. Ekonomicko-manazerske Spektrum, 13(1), 96108. https://doi.org/10.26552/ems.2019.1.96-108

Krizanova, A., Moravcikova, K., \& Rypakova, M. (2016). The social area of corporate social responsibility focusing on social policy. In G. Lee (Ed.), ICASS 5th International Conference on Applied Social Science (pp. 339-344). Bangkok, Thailand.

Lazonick, W., Mazzucato, M., \& Tulum, Ö. (2013). Apple's changing business model: What should the world's richest company 
do with all those profits? Accounting Forum, 37(4), 249-267. https://doi.org/10.1016/j. accfor.2013.07.002

Leite, F. S. F., de Figuêiredo, H. S., Hugo, S., \& Crisóstomo, V. L. (2013). Applicability of the profit per employee as a measure of business performance. Revista de Gestão, Finanças e Contabilidade, 3(3), 75-93. Retrieved from http://oaji.net/articles/2014/1191-1408982842.pdf

Lemańska-Majdzik, A., \& Okręglicka, M. (2015). Determinants and areas of an organisations' success - literature review. In H. Kratochvílová \& R. Kratochvíl (Eds.), Proceedings of IAC-MEM 2015 in Vienna. (pp. 32-42). Prague: Czech Institute of Academic Education.

Li, Y., Su,-Z. F., \& Liu, Y. (2010). Can strategic flexibility help firms profit from product innovation? Technovation, 30(5-6), 300-309. https://doi. org/10.1016/j.technovation.2009.07.007

Ljung, G. M., \& Box, G. E. (1978). On a measure of lack of fit in time series models. Biometrika, 65(2), 297-303. https://doi. org/10.1093/biomet/65.2.297

Manish, G. P., \& Sutter, D. (2016). Mastery versus profit as motivation for the entrepreneur: How crony policies shape business. Journal of Entrepreneurship and Public Policy, 5(1), 95-112. https://doi.org/10.1108/JEPP-10-2015-0032

McWilliams, A., \& Siegel, D. (1997). Event studies in management research: Theoretical and empirical issues. Academy of Management Journal, 40(3), 626-657. https:// doi.org/10.5465/257056

McWilliams, A., \& Siegel, D. (2000). Corporate social responsibility and financial performance: correlation or misspecification? Strategic Management Journal, 21(5), 603-609. https://doi.org/10.1002/(SICl)1097-0266(200005) 21:5<603::AID-SMJ101>3.0.CO;2-3

McWilliams, A., \& Siegel, D. (2001a). Corporate social responsibility: A theory of the firm perspective. Academy of Management Review, 26(1), 117-127. https://doi. org/10.2307/259398

McWilliams, A., \& Siegel, D. (2001b). Profit maximizing corporate social responsibility. Academy of Management Review, 26(4), 504-505. https://doi.org/10.5465/amr.2001.5393880

McWilliams, A., Siegel, D. S., \& Wright, P. M. (2006). Corporate social responsibility: Strategic implications. Journal of Management Studies, 43(1), 1-18. https://doi.org/10.1111/ j.1467-6486.2006.00580.x
Meals, D. W., Spooner, J., Dressing, S. A., \& Harcum, J. B. (2011). Statistical analysis for monotonic trends. Tech Notes, 6, 1-23.

Moravcikova, K., \& Krizanova, A. (2016). Impact of corporate social responsibility on the company's reputation. In H. Zhang (Ed.), ICMIBI International Conference on Applied Social Science and Business (pp. 20-25). Singapore: Singapore Management and Sports Science Institute.

Mulligan, T. (1986). A critique of Friedman, Milton essay the social-responsibility of business is to increase its profits. Journal of Business Ethics, 5(4), 265-269. https://doi. org/10.1007/BF00383091

Pettitt, A. N. (1979). A non-parametric approach to the change-point problem. Journal of the Royal Statistical Society: Series C (Applied Statistics), 28(2), 126-135. https://doi. org/10.2307/2346729

Petricevic, O., \& Teece, D. J. (2019). The structural reshaping of globalization: Implications for strategic sectors, profiting from innovation, and the multinational enterprise. Journal of International Business Studies, 50(9), 1487-1512. https://doi.org/10.1057/s41267-019-00269-x

Pinxterhuis, I., Dirks, S., Bewsell, D., Edwards, P., Brazendale, R., \& Turner, J. A. (2019). Co-innovation to improve profit and environmental performance of dairy farm systems in New Zealand. Rural Extension \& Innovation Systems Journal, 14(2), 23-33.

Podhorska, I., Gajanova, L., Kliestikova, J., \& Popescu, G. H. (2019). Analysis of Internally Generated Goodwill Indicators: A Case Study of the Slovak Republic. Organizacija, 52(4), 271-285. https://doi.org/10.2478/orga-2019-0017

Pohlert, T. (2020). Non-parametric trend tests and change-point detection. Creative Commons License (CC BY-ND 4.0). Retrieved from https://cran.r-project.org/web/packages/ trend/vignettes/trend.pdf

Primeaux, P. (1997). Business Ethics in Theory and Practice: Diagnostic Notes B. A Prescription for Profit Maximization. Journal of Business Ethics, 16(3), 315-322. https://doi. org/10.1023/A:1005715916297

Primeaux, P., \& Stieber, J. (1994). Profit maximization: The ethical mandate of business. Journal of Business Ethics, 13(4), 287-294. https://doi.org/10.1007/BF00871675

Rahman, A., Rozsa, Z., \& Cepel, M. (2018). Trade Credit and Bank Finance Evidence from the Visegrad Group. Journal of 
Competitiveness, 10(3), 132-148. https://doi. org/10.7441/joc.2018.03.09

Rahman, A., Belas, J., Kliestik, T., \& Tyll, L. (2017). Collateral requirements for SME loans: empirical evidence from the Visegrad countries. Journal of Business Economics and Management, 18(4), 650-675. http://doi.org/10. 3846/16111699.2017.1357050

Razali, N. M., \& Wah, Y. B. (2011). Power comparisons of Shapiro-Wilk, KolmogorovSmirnov, Lilliefors and Anderson-Darling tests. Journal of Statistical Modeling and Analytics, 2(1), 21-33.

Robson, G. (2019). To profit maximize, or not to profit maximize: For firms, this is a valid question. Economics \& Philosophy, 35(2), 307-320. https://doi.org/10.1017/ S0266267118000329

Rowland, Z. (2019). Business environment assessment based on profits: A comparative study of the Czechia and Slovakia. In D. Dukic, T. Studzieniecki, \& J. Grzinic (Eds.), Economic and social development: 49th International Scientific Conference on Economic and Social Development - "Building Resilient Society" (pp. 569-578). Varazdin: Varazdin Development and Entrepreneurship Agency.

Schwab, K. (2014). The Global Competitiveness Reports 2013-2014. Geneva: World Economic Forum.

Schwab, K. (2019). The Global Competitiveness Reports 2019. Geneva: World Economic Forum

Shahriar, A. Z. M., Schwarz, S., \& Newman, A. (2016). Profit orientation of microfinance institutions and provision of financial capital to business start-ups. International Small Business Journal, 34(4), 532-552. https://doi. org/10.1177/0266242615570401

Shapiro, S. S., \& Wilk, M. B. (1965). An analysis of variance test for normality (complete samples). Biometrika, 52(3/4), 591-611. http://doi.org/10.2307/2333709

Siegel, D. (2001). Do British companies really need a minister to make them socially responsible? Parliamentary Brief, 7, 7-8.

Singer, A. (2013). What is the best way to argue against the profit-maximization principle? Business Ethics Journal Review, 1(12), 76-81. http://doi.org/10.12747/bejr2013.01.12

Singh, A. S., \& Masuku, B. (2014). Sampling techniques \& determination of sample size in applied statistics research: An overview. International Journal of Economics, Commerce and Management, 2(11), 1-22.
Smith, J. (2018). Efficiency and Ethically Responsible Management. Journal of Business Ethics, 150(3), 603-618. https://doi. org/10.1007/s10551-016-3175-x

Stanovcic, T., Bacovic, M., Pekovic, S., Jovanovic, J., \& Savovic, I. (2016). The role of human resource practices on profits generated by the innovations: The role of top management support and regularity of employees meetings. International Journal for Quality Research, 10(4), 839-845. https://doi.org/10.18421/ IJQR10.04-13

Svabova, L., \& Durica, M. (2019). Being an outlier: A company non-prosperity sign? Equilibrium. Quarterly Journal of Economics and Economic Policy, 14(2), 359-375. https://doi.org/10.24136/eq.2019.017

Su, Z. F., Peng, J. S., Shen, H., \& Xiao, T. (2013a). Technological Capability, Marketing Capability, and Firm Performance in Turbulent Conditions. Management and Organization Review, 9(1), 115-137. http://dx.doi. org/10.1111/j.1740-8784.2011.00280.x

Su, Z. F., Xie, E., Liu, H., \& Sun, W. (2013b). Profiting from product innovation: The impact of legal, marketing, and technological capabilities in different environmental conditions. Marketing Letters, 24(3), 261-276. https://doi.org/10.1007/ s11002-012-9214-1

Toms, J. S. (2010). Calculating profit: A historical perspective on the development of capitalism. Accounting, Organizations and Society, 35(2), 205-221. https://doi. org/10.1016/j.aos.2009.06.002

Trading Economy. (2019). Ease of Doing Business. Retrieved from https://tradingeconomics. com/country-list/ease-of-doing-business

Trigos, F., \& López, E. M. (2019). About tooling capacity for the vulcanising planning decision problem to improve strategic business profit. International Journal of Production Research, 1-12. https://doi.org/10.1080/00207 543.2019.1660820

Tuyls, R., \& Pera, A. (2019). Innovative datadriven smart urban ecosystems: Environmental Sustainability, Governance Networks, and the Cognitive Internet of Things. Geopolitics, History, and International Relations, 11(1), 116-121. https://doi.org/10.22381/GHIR11120198

Vagner, L. (2016). Controlling as a competitiveness tool in the global market. In Globalization and Its Socio-economic Consequences: 16th International Scientific Conference, 5th-6th October 2016, Rajecke 
Teplice, Slovak Republic: Proceedings (pp. 2260-2266). Žilina: University of Žilina.

Vagner, L., \& Zadnanova, S. (2019). Nonprofit organizations and their possibilities of measuring efficiency. In 8th International Scientific Symposium Economy of Eastern Croatia Vision and Growth. Osijek, Croatia (pp. 1159-1165). Osijek: University of Osijek.

Vranceanu, R. (2014). Corporate profit, entrepreneurship theory and business ethics. Business Ethics: A European Review, 23(1), 50-68. https://doi.org/10.1111/beer.12037

Wang, T., \& Bansal, P. (2012). Social responsibility in new ventures: Profiting from a long-term orientation. Strategic Management Journal, 33(10), 1135-1153. https://doi. org/10.1002/smj.1962

Warriyar, K. V. V., Abraham, B., \& Variyath, A. M. (2016). Robustness of Some Portmanteau Correlation Tests in Financial Time Series. American Journal of Mathematical and Management Sciences, 35(1), 67-76. https://doi.org/10.1080/01966324.2015.1082451

Yazici, B., \& Yolacan, S. (2007). A comparison of various tests of normality. Journal of Statistical Computation and Simulation, 77(2), 175-183. https://doi. org/10.1080/10629360600678310 